\title{
1. \\ Synthesis of 11a - Aza-5-deoxi-pterocarpans Via Palladium Aza-arylation of Dihydronaphtalen by Orto-iodoanilines Derivatives
}

\author{
Camilla D. Buarque ${ }^{a}$, Kevin C. de Fraga ${ }^{a}$ and Paulo R. R. Costa ${ }^{b}$ \\ ${ }^{a}$ Departamento de Química, Pontifícia Universidade Católica do Rio de Janeiro, Rua Marquês de S. Vicente, \\ 225, Gávea - Rio de Janeiro, RJ-Brasil-22453-900 ㄴ Laboratório de Química Bioorgânica, NPPN, CCS, Ilha \\ da Cidade Universitária, Universidade Federal do Rio de janeiro, Rio de Janeiro, RJ 21941-590, Brazil.
}

\section{*e-mail: Camilla-buarque@puc-rio.br}

Keywords: aza-arylation, dihydronaphtalen, o-iodoanilines

\section{INTRODUCTION}

During the course of our studies aiming the discovery of new antineoplasic and antiparasitary compounds, we recently described the synthesis of the aza-dehydropterocarpan 1a (Figure 1). ${ }^{1}$ In order to know more about the structural features required for the observed activities of $\mathbf{1 a}$, we report in this work the synthesis of compounds $\mathbf{1} \mathbf{b}-\mathbf{d}$ and $\mathbf{2 a - c}$. Our first goal was to modify the substituent at the nitrogen atom in the C-ring (1b-c) to see if this moiety is part of the pharmacophore. In analogues $\mathbf{2} \mathbf{a}-\mathbf{b}$, halogen atoms at D-ring were introduced to target diverse set of relevant medicinal proteins due to halogen bond ${ }^{2}$. Trying to understand more about the mechanism of the antineoplasic activity, cell death was evaluated by flow cytometry.

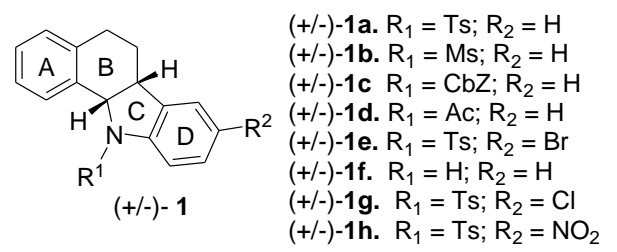

Figure 1. Aza-deoxi-pterocarpans 1

\section{RESULTS AND DISCUSSION}

Compounds 1 were prepared by a palladium catalyzed aza-arylation of dihydronaphthalen (3) with o-iodoaniline derivatives (4) in different conditions leading respectively to $N$-tosyl, $N$-mesyl and $N$-CBZ-5-deoxi-aza-pterocarpns $\mathbf{1 a}, \mathbf{1 b}$ and $\mathbf{1 c}$ as shown in Scheme1, with yields ranging from 41 to $85 \%$ using acetone as solvent and silver carbonate (3 equiv.). All these reactions were conducted in aproximately 8 hours. When we used PEG400 as solvent, a benign solvent commonly used in green chemistry, compound 1a was obtained in 1 hour using 1.2 equiv. of silver carbonate under termic conditions or 30 minutes under microwave conditions. In contrast, the aza-arylation of $\mathbf{3}$ did not work when $\mathrm{N}$-acetyl- o-iodoaniline (4d) or unprotected $\mathrm{o}$-iodoanilin $(\mathbf{4 f})$ were allowed to react with 3.
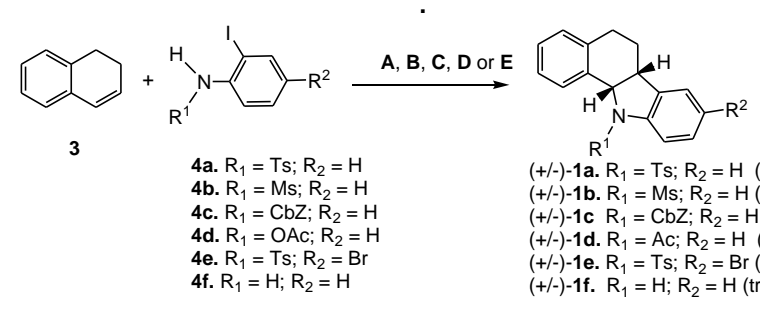

$(+/-)-1$ a. $R_{1}=T s ; R_{2}=H(88 \%)$ $+/-$-)-1b. $R_{1}=M s ; R_{2}=H(40 \%)$ $+/-)-1 c \quad R_{1}=\mathrm{CbZ} ; \mathrm{R}_{2}=\mathrm{H}(67 \%)$ $+/-$ - $\mathbf{1 d}$. $\mathrm{R}_{1}=\mathrm{Ac} ; \mathrm{R}_{2}=\mathrm{H}$ (traces) $(+-)-1$ e. $R_{1}=\mathrm{Ts} ; \mathrm{R}_{2}=\mathrm{Br}(75 \%)$ $(+/-)$-1f. $R_{1}=H ; R_{2}=H$ (traces)

A. acetone, $10 \mathrm{~mol} \% \mathrm{Pd}(\mathrm{OAc})_{2}, 3$ equiv. $\mathrm{Ag}_{2} \mathrm{CO}_{3}, 70^{\circ} \mathrm{C}$, 8 horas B. acetone, $10 \mathrm{~mol} \% \mathrm{Pd}(\mathrm{OAc})_{2}, 1.5$ equiv. $\mathrm{Ag}_{2} \mathrm{CO}_{3}, 70^{\circ} \mathrm{C}, 8$ horas C. acetone, $5 \mathrm{~mol} \% \mathrm{Pd}(\mathrm{OAc})_{2}, \quad 3.0$ equiv. $\mathrm{Ag}_{2} \mathrm{CO}_{3}, 70^{\circ} \mathrm{C}, 8$ horas D. PEG400, $10 \mathrm{~mol} \% \mathrm{Pd}(\mathrm{OAc})_{2}, 1.2$ equiv. $\mathrm{Ag}_{2} \mathrm{CO}_{3}, 200^{\circ} \mathrm{C}, 10 \mathrm{~min}$. E. PEG400, $10 \mathrm{~mol} \% \mathrm{Pd}(\mathrm{OAc})_{2}, 1.2$ equiv. $\mathrm{Ag}_{2} \mathrm{CO}_{3}, 120^{\circ} \mathrm{C}, 10 \mathrm{~min}$. $\mathrm{MW}$ Scheme 1

Compounds $\mathbf{2 a}$ and $\mathbf{2} \mathbf{b}$ were obtained from $\mathbf{1 a}$ by halogenation with NCS or nitration with $\mathrm{HNO}_{3}$ fum., in chloroform solution. In all cases the reaction was chemoselective for D-ring (Scheme 2).

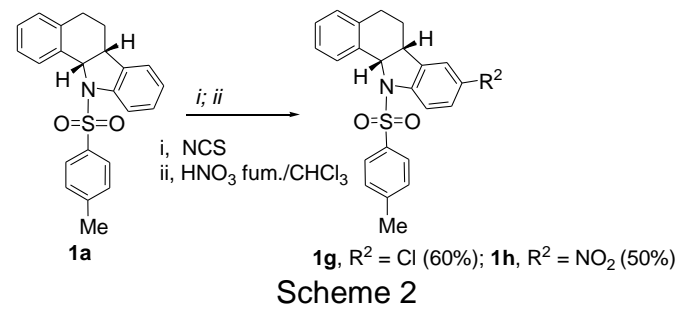

\section{CONCLUSION}

In conclusion, we have developed the Heck azaarylation of dihydronaphtalen by o-iodoanilines derivatives in good to excellent yields. PEG400 was the best solvent to obtain 1a under termic and microwave conditions.

\section{ACKNOWLEDGEMENTS}

CAPES, CNPq, FAPERJ

\section{REFERENCES}

${ }^{1}$ Buarque, C.D.; Militão Gardênia C.G.; Lima, Dayse .J. B.; Costa-Lotufo Letícia V.; Pessoa, Cláudia.; de Moraes, Manoel Odorico, Cunha-Junior, Edézio Ferreira; Torres-Santos, Eduardo Caio; Netto, Chaquip D.; Costa, Paulo R.R.. Bioorganic \& Medicinal Chemistry 2011, 19, 6885.

${ }^{2}$ Wilcken, R.; ${ }^{2}$ Zimmermann, M. O.; Lange, A.; Joerger, A.C.and Boeckler F. M. Principles and Applications of Halogen Bonding in Medicinal Chemistry and Chemical Biology J. Med. Chem. 2013, 56, 1363 